\title{
Irish merchants and seamen in late medieval England
}

\begin{abstract}
$\mathrm{M}$ ost studies of Anglo-Irish relations in the middle ages understandably concentrate on the activity of the English in Ireland, and unintentionally but inevitably this can leave the impression that the movement of people was all one way. But this was not so, and one group who travelled in the opposite direction were some of the merchants and seamen involved in the Anglo-Irish trade of the period. Irish merchants and seamen travelled widely and could be found in Iceland, Lisbon, Bordeaux, Brittany and Flanders, but probably their most regular trade remained with their closest neighbour and political overlord: England. They visited most western and southern English ports, but inevitably were found most frequently in the west, especially at Chester and Bristol. The majority of them stayed for a few days or weeks, as long as their business demanded. Others settled permanently in England, or, perhaps more accurately, re-settled in England, for those who came to England both as settlers and visitors were mainly the Anglo-Irish of the English towns in Ireland and not the Gaelic Irish. This makes it difficult to estimate accurately the numbers of both visitors and settlers, because the status of the Anglo-Irish was legally that of denizen, and record-keepers normally had no reason to identify them separately. They may, therefore, be hard to distinguish from native Englishmen of similar name outside the short periods when governments (central or urban) temporarily sought to restrict their activities. However, the general context within which they worked is quite clear, and this article considers three main aspects of that context: first, the pattern of the trade which attracted Irish merchants to England; second, the role of the Irish merchants and seamen in the trade; and third, examples of individual careers of merchants and seamen who settled in England.
\end{abstract}

\section{I}

Direct Anglo-Irish trade was a regular exchange of everyday goods. It was attractive because the two markets were geographically close and had goods each other wanted. The economic attraction was, of course, reinforced by political ties. Two fifteenth-century English treatises devote generous space to descriptions of Ireland's trade with England. To the author of the much-quoted political treatise, The libelle of Englyshe polycye, written about 1436, Ireland was not only an essential buttress for England's safety against her enemies, but also a good trading partner supplying hides and skins (marten, deer, otter, squirrel, hare, sheep, lamb, fox, kid and coney), 
wool and cloth (woollen falding and linen), and fish (especially hake, salmon and herring). ${ }^{1}$ Although Ireland's main exports of hides and wool were not needed by the English, the other goods were very welcome. The author of The noumbre of weyghtes, a purely commercial treatise written a little later than the Libelle, noted that Flanders was the main market for salt hides, described as Ireland's chief goods, where they sold for $£ 18$ the last, a better price than in England; but he also noted linen cloth, skins (marten, otter, and black lamb like budge), horses and fish as commodities sent to England. In particular, he noted how cheap herring and salmon were in Ireland, and quoted the proverb 'Herring of Sligo and salmon of Bamme [recte Bann] have made in Bristol many a rich man'. In return he advised merchants to send to Ireland English cloth, steel, spices, haberdashery and Spanish iron. ${ }^{2}$ Although Irish merchants were counted denizens and thus paid customs duties at the same rate as English merchants, Ireland itself was always reckoned a foreign country for trading purposes. Therefore, usefully for historians, commodities sent between Ireland and England were fully dutiable as part of foreign trade and thus were recorded. The surviving English customs accounts for the late fourteenth and fifteenth centuries make the pattern of Anglo-Irish trade and the world of the Irish merchants easier to trace. ${ }^{3}$ They confirm the accuracy of the Libelle and The noumbre of weyghtes on the main goods, and show that fish was always overwhelmingly the main import to England: in $1403-4$ its value reached $£ 1,800$ among imports of $£ 2,099$, and in the late fifteenth century it regularly reached $£ 1,000$ to $£ 2,000$ a year, normally around 70 to 80 per cent of trade by value. ${ }^{4}$ The accounts also identify shippers by name, and ships by name and home port, which helps us to trace the pattern of trade.

The centres of Irish commercial activity in England, unsurprisingly, were Chester and Bristol, ports which combined proximity with extensive hinterlands. Most of Chester's overseas trade was directed at Ireland until the

${ }^{1}$ The libelle of Englyshe polycye, ed. Sir George Warner (Oxford, 1924), 11 656-783. This political treatise was written to encourage England to protect its trade and therefore keep safe its shipping and dominions.

${ }^{2}$ B.L., Cott. MS Vesp. E IX, ff 94rv, 101-2, now printed in Stuart Jenks, 'Werkzeug des spätmittelalterlichen Kaufmanns: Hansen und Engländer im Wandel von memoria zur Akte (mit einer Edition von The Noumbre of Weyghtys)' in Jahrbuch für fränkische Landesforschung, Bd lii (1992), pp 304,308. This was a merchant manual and does not concern itself with politics. Both tracts listed minerals as exports. The Libelle included gold and silver (following classical sources, and possibly to make Ireland seem more valuable); The noumbre of weyghtys mentioned iron, which was more often an import.

${ }^{3}$ Customs accounts are tax returns and have a number of shortcomings as records of trade, but they are sufficient to trace trends and patterns.

${ }^{4}$ P.R.O., E 122/17/10; Table 3 below. For a survey of Anglo-Irish trade see W. R. Childs, 'Ireland's trade with England in the later middle ages' in Ir. Econ. \& Soc. Hist., ix (1982), pp 5-33; Wendy Childs and Timothy O'Neill, 'Overseas trade' in Art Cosgrove (ed.), A new history of Ireland, ii: Medieval Ireland, 1169-1534 (Oxford, 1987), pp 492-524. 
beginning of the sixteenth century. At first Irish shipping predominated, and, up to the mid-fifteenth century, two dozen Irish vessels a year might unload there, but numbers then dropped to fewer than a dozen a year, as ships of Chester, Liverpool and the Isle of Man increasingly entered the trade. ${ }^{5}$ Chester's links, as reflected in the active shipping, were predominantly with the Dublin area. Of a total of 332 incoming Irish ships with recorded port names between 1427 and 1499, three-quarters came from Dublin, Howth, Malahide and their immediate vicinity, and the majority of the rest came from the northern area between Carrickfergus and Wicklow. Only six came from the south, from Wexford, Waterford and Youghal. ${ }^{6}$ The only change in ports over the century was a rise in ships of Howth and Malahide, while those of Dublin and Drogheda decreased. This probably reflects increasing navigational difficulties in the harbours of Dublin and Drogheda at the end of the middle ages.

Bristol was possibly an even greater centre of Irish trade, but the port was less dependent on it than Chester, because of its greater trade with continental Europe. Unlike Chester, at Bristol English shipping predominated in the Anglo-Irish trade, but in the late fourteenth century normally half a dozen and sometimes a dozen Irish ships a year brought cargoes, and in the late fifteenth century numbers rose substantially, with up to 24 Irish ships a year arriving. ${ }^{7}$ Bristol's trading partners were different from Chester's and were overwhelmingly with the southern Irish ports. In the late fourteenth century, of 171 Irish ship movements recorded there, 91 per cent were by ships from harbours between Wexford and Kinsale; only 11 ships came from further north (Dublin and Drogheda), and only four from the far west (Dingle, Limerick and Galway) (see Table 1A). In the late fifteenth century, of the 381 Irish ship movements recorded at Bristol and Bridgwater, no less than 97 per cent came from that southern area, with only two movements from the north (Howth and Malahide), and only four from the west (Dingle and Limerick) (see Table 1B). Over the period there was a significant shift within the shipping to a concentration of vessels from the three major ports of Cork, Waterford and Wexford. Ships from Kinsale Bay dropped significantly, from 34 per cent in the late fourteenth century to 9 per cent in the late fifteenth century, and a rise from 11 to 15 per cent by boats of Youghal did not make up the difference; Cork's shipping rose from 8 to 18

${ }^{5}$ Chester fell outside the national customs system, but duties were collected locally, and some accounts survive for the fifteenth century: see K. P. Wilson (ed.), Chester customs accounts, 1301-1566 (Record Society for Lancashire and Cheshire, CXI, Liverpool, 1969), pp 8-14, 101-42, 149--52; Chester Record Office (henceforth C.R.O.), Sheriff's Books 1-5.

${ }^{6}$ C.R.O., Sheriff's Books 1-4; see Childs, 'Ireland's trade with England', Table 7 (p. 29). Numbers are as follows:

\begin{tabular}{|c|c|c|c|c|c|c|}
\hline Dublin & 124 & Rush & 14 & Portrane & 7 & Wexford \\
\hline Howth & 64 & Carrickfergus & 8 & Clontarf & 4 & Waterford \\
\hline Drogheda & 42 & Baldoyle & 8 & Lusk & 1 & Youghal \\
\hline Malahide & 42 & Rogerstown & 8 & Wicklow & 4 & \\
\hline
\end{tabular}


Table 1: Geographical spread of Irish shipping at Bristol and Bridgwater

A: Ship movements in the Irish trade at Bristol, 1376-1404

\begin{tabular}{lrrr}
\hline Homeports & Outward & Inward & Total movements \\
\hline Bristol & 108 & 33 & 141 \\
English + Welsh & 25 & 36 & 61 \\
Unidentified & 4 & 4 & 8 \\
\hline Waterford & 31 & 9 & 40 \\
Endelford 1 /Kinsale & 41 & 17 & 58 \\
Youghal & 15 & 4 & 19 \\
Cork & 12 & 1 & 13 \\
Ross & 6 & 3 & 9 \\
Wexford & 10 & 5 & 15 \\
Drogheda & 4 & 2 & 5 \\
Dublin & 2 & 3 & 2 \\
Limerick & 2 & 0 & 1 \\
Galway & 1 & 0 & 1 \\
Dingle & 1 & 0 & 2 \\
Other & 1 & 1 & \\
\hline
\end{tabular}

B: Ship movements in the Irish trade at Bristol and Bridgwater, 1460-97

\begin{tabular}{|c|c|c|c|}
\hline Homeports & Outward & Inward & Total movements \\
\hline Bristol & 94 & 85 & 179 \\
\hline English + Welsh & $45(61)$ & $174(50)$ & 330 \\
\hline \multicolumn{4}{|l|}{ Unidentified English, } \\
\hline Welsh or Irish & $9(47)$ & $12(39)$ & 107 \\
\hline Foreign & 6 (1) & $4(1)$ & 12 \\
\hline Waterford & $44(26)$ & $53(12)$ & 135 \\
\hline Kinsale & $9(6)$ & $13(6)$ & 34 \\
\hline Youghal & $4(26)$ & $13(13)$ & 56 \\
\hline Cork & $19(16)$ & $26 \quad(8)$ & 69 \\
\hline Ross & 1 (1) & 3 & 5 \\
\hline Wexford & $8(27)$ & $11(22)$ & 68 \\
\hline Drogheda & 1 & 1 & 2 \\
\hline Dublin & 0 & 1 & 1 \\
\hline Limerick & 0 & 1 & 1 \\
\hline Galway & 0 & 0 & 0 \\
\hline Dingle & $0 \quad(2)$ & $0 \quad(1)$ & 3 \\
\hline Other $^{3}$ & 0 (1) & $5(1)$ & 7 \\
\hline
\end{tabular}

'Endelford was an early name for Kinsale harbour: see T. J. Westropp, 'Early Italian maps of Ireland, 1300-1600' in R.I.A. Proc., xxx (1912-13), sect. C, pp 364, 370.

${ }^{2}$ One Kilkenny outward; one 'of Ireland' inward.

${ }^{3}$ At Bristol, one 'Balihak', four 'Nangle' inward; at Bridgwater, one Howth outward; one Malahide inward.

Sources: P.R.O., E 122/15/8,16/2,4,5,9, 11, 13, 15, 17-24, 26-8, 30,31,34, 17/1,4-6, 9, 10, 12, 40/12, 17 (Bristol, 1376-1404, most accounts are of exports only); ibid., E 122/18/39, 19/1, 3, 4, 6-14, 20/1, 5, 7, 9, 161/31 (Bristol, 1461-93); ibid., E 122/26/1, 2, 5, 7-14, 16, 20, 28/9 (Bridgwater, 1460-97, numbers of ship movements at Bridgwater are given in brackets). Further details of dates are in Childs, 'Ireland's trade with England', Table 5 (p. 26). 
per cent, Wexford's from 9 to 18 per cent, and Waterford's from 23 to a dominant 35 per cent. This shift no doubt reflects the increasing instability in English-held lands in the south, and a certain withdrawal to the safer southeast. The drop in shipping from the far west was possibly less significant, since the number of western Irish ships visiting Bristol was always so low. Despite the proverb about herring of Sligo, there is only one clear reference to direct shipping contact with Sligo, and the fish must have been transhipped on boats of the south-east. ${ }^{8}$ Slightly greater contact with Bristol is documented for Galway: Geoffrey Blake of Galway exported cloth in 1389; Nicholas Skeret of Galway did so in 1437; and Dennis Galway was employed as a Bristol shipmaster in the 1470 s. $^{9}$ Limerick contacts were the most substantial on the west coast. In 1401 John Hethe's Trinity was intended for Limerick when it was driven to Dingle; John Bannebury, who came from Limerick, became a substantial Bristol merchant; and a Limerick ship at Bristol in 1485-6 brought one of the richest cargoes known in Irish trade, valued at $£ 310$. ${ }^{10}$

Away from Chester and Bristol, Irish ships and merchants thinned out. The Welsh ports with their more limited hinterlands were less attractive to them, ${ }^{11}$ although the interest of Wales in Irish trade is visible in the frequent ships of Tenby, Milford and Haverford which brought or transhipped Irish goods to Bristol, and the occasional vessel from Beaumaris with Irish goods at Chester. Beyond Bristol, in Somerset and on the northern coasts of Devon and Cornwall, Irish ships and merchants were also less frequent visitors, until in the late fifteenth century Wexford and Waterford ships became more regular visitors at Bridgwater and Barnstaple, alongside a few vessels of Youghal, Kinsale, Cork and Drogheda. In south Devon ships of Youghal and Kinsale occasionally appeared with fish. This relatively low Irish trading activity in the south-west is surprising, given that this area recorded some of the highest numbers of Irish settlers in $1440,{ }^{12}$ but Somerset's links were maintained by many small boats of Minehead, and Devon's links also were maintained through many small south-western vessels fetching fish. An inquiry in 1476 into Devon's trade showed that the Irish route was the second busiest after Brittany. ${ }^{13}$ As we move east along the southern English coast there is much less evidence of regular Anglo-Irish trade, but Irish ships

${ }^{8}$ P.R.O., E $122 / 16 / 2$.

${ }^{9}$ Cal. pat. rolls, 1391-6, p. 594; Henry Bush, Bristol town duties (Bristol, 1828), pp 17-25; P.R.O., E 122/19/13,14, 20/1,5,7.

${ }^{10}$ Cal. pat. rolls, $1399-1401$, p. 451; T. P. Wadley, Notes and abstracts of wills contained in the volume entitled the Great Orphan Book and Book of Wills in the Council House at Bristol (Bristol, 1886), p.70; P.R.O., E 122/20/5.

${ }^{11}$ E. A. Lewis, 'A contribution to the commercial history of medieval Wales' in $Y$ Cymmrodor, xxiv (1913), pp 104-63.

${ }^{12}$ J. L. Bolton, 'Irish migration to England in the late middle ages: the evidence of 1394 and 1440 ', Table 1 (above, pp 5-7); see also S. L. Thrupp, 'A survey of the alien population in England in 1440' in Speculum, xxxii (1957), pp 266-7, 270-72.

${ }^{13}$ P.R.O., E 159/253, Recorda, Trinity, m. 25. 
sometimes sheltered while en route to Brittany or Flanders. ${ }^{14}$ In London and on the east coast Irish ships were rare, but there were Irish immigrants among the London merchants, and several seem to have been particularly tied to Iberian trade in association with merchants from Bristol. ${ }^{15}$ Irish merchants were therefore familiar enough in all the harbours round to London, but numerous only in Chester and Bristol.

The scale of Irish trade is most easily quantifiable in Bristol because the royal customs collectors carefully recorded both last ports of call and destinations for ships clearing customs. There probably two-thirds of shipping movements and about one-fifth of the trade by value were with Ireland. In $1485-6$, for example, 72 per cent of recorded outward voyages were to Ireland, 58 per cent of inward voyages came from Ireland, and at least 63 per cent of the active merchants shipped to or from Ireland. ${ }^{16}$ The total cargo values were less significant than this suggests, since many consignments were small and the goods were of relatively low value, but still 11 per cent of cloth exports and 23 per cent of the value of other goods exported went to Ireland and 20 per cent of imported goods came from Ireland. ${ }^{17}$ The ships and cargoes were of modest size: of nearly 100 ships involved, only seven of the Irish and two of the Bristol ships carried goods worth over $£ 40$, most carried cargoes valued at under $£ 30$, and quite a few under $£ 10$. The merchants were also generally of modest status. In that year 71 per cent of shippers handled only one consignment, and only 7 per cent had more than three shipments. Similarly, 69 per cent of merchants individually invested less than $£ 10$, and only fifteen individuals invested more than $£ 40$. Of those, however, two were substantial traders. The greatest investment of $£ 154$ came from John Stephens, who was one of the few leading Bristol men with substantial interests in Ireland,$^{18}$ and second to him came William Clifford, possibly an Irishman and an extremely frequent shipper in the Irish trade, whose investment that year reached £118. Nonetheless, these many small shipments built up to a substantial part of Bristol's trade, and Irish ships, seamen and shippers were very familiar sights on Bristol quays.

The trade at Bristol was part of an intricate trade in the Bristol Channel,

\footnotetext{
${ }^{14}$ Customs accounts show few Irish merchants trading in the ports of Dorset, Hampshire or Kent, but Irish ships were blown in en route for Flanders. At various times Irish merchants at Southampton, Chichester and Sandwich produced their customs cockets from Youghal, Cork, Dungarvan, Waterford, Wexford, Dublin and Drogheda to prove they had paid customs on their exports of hides for Flanders: see Cal. close rolls, 1339-41, p. 591; ibid., 1349-54, pp 25-6; ibid., 1369-74, p. 213; ibid., $1381-5$, p. 72 ; ibid., 1402-5, p. 221.

${ }^{15}$ See below, p. 34.

${ }^{16}$ P.R.O., E 122/20/5; for the commodities this year see Tables 2 and 3 .

${ }^{17}$ The exports were 395 out of a total of 3,646 cloths, and $£ 232$ worth of other goods out of a total of $£ 988$; the imports were worth $£ 1,790$ out of a total value of $£ 8,861$. If wine is included in the import values at the occasional customs valuation of $£ 4$ per tun, the total import value rises to $£ 13,721$, and the Irish trade accounts for 13 per cent.

${ }^{18}$ Apart from Stephens, one or two of the other major Bristol figures - John Pynke, John Esterfield and Robert Baron - occasionally traded with Ireland.
} 
which meant that it drew Irish merchants and seamen to other ports in the area. At Bristol itself Irish shipping was prominent in the inward trade, while Bristol shipping dominated the outward trade; movements were more balanced in the Bristol Channel as a whole, since Irish vessels which left Bristol with little or no cargo for Ireland might call at Bridgwater to pick up Somerset cloth, beans and peas. ${ }^{19}$ Few Irish ships or merchants, however, seem to have made more complex journeys, combining trade with England and the Continent, although we can trace Portuguese and Breton ships doing this, and very occasionally a Bristol ship sailed out to Ireland and back from Iberia. This separation of Anglo-Irish from both Anglo-continental and Irish-continental trade was not through lack of opportunity, since Irish ships and merchants visited many northern European markets, but seems to have been by choice. It was no doubt a matter of the different goods demanded by the markets, and possibly of the different size of vessel used. The division of routes is also apparent among the Irish merchants who settled in Bristol. Those Irish immigrants who became particularly active in Bristol's Iberian trade retained little interest in direct Anglo-Irish trade, possibly because they perceived greater opportunity for profits in Iberian goods than in Irish fish and operated larger vessels in that trade than were useful in the fish trade.

The Anglo-Irish trade overall cannot be said to be very significant in England's national picture. For instance, while in the late fourteenth century sometimes 5 per cent of England's total cloth exports were sent to Ireland through Bristol, by the fifteenth century this had dropped to only 1 per cent. On the other hand, the trade was always very important to Chester and Bristol. It was undoubtedly Chester's major branch of trade, although it cannot be quantified, and at Bristol it was a solid regular trade over two centuries, which accounted for between one-fifth and over one-quarter of the trade. In the late fourteenth century Ireland took 20 to 25 per cent of the town's exported cloth and accounted for up to 31 per cent of inward cargo values; although cloth exports to Ireland dropped in the late fifteenth century to between 7 and 11 per cent, the rising value of miscellaneous exports made up for the drop in value, ${ }^{20}$ and Ireland still accounted for about 30 per cent of Bristol's inward cargo values. The cause for the decline in the cloth trade is not clear. Possibly Ireland did not yet share the new economic expansion of the period and therefore demand for cloth fell; possibly the expansion of the Iberian market simply drew cloth away from Ireland as Bristol merchants adjusted to the loss of Gascony by turning to Iberia, where in return for the cloth they could acquire higher-cost imports on which greater profits were made. Nonetheless, in the difficult period around the loss of the Gascon market and for some time afterwards the solidity of Irish trade must have been welcome to many Bristol merchants. The trade

${ }^{19} \mathrm{See}$, for instance, the voyages of the Trinity of Waterford and the John of Cork, which called both at Bristol and at the Bridgwater creek of Axewater in 1485-6 (P.R.O., E 122/20/5, 26/13); for further details see Childs, 'Ireland's trade with England', pp 21-3.

${ }^{20}$ See n. 21. 
Table 2: Exports from Bristol to Ireland

\begin{tabular}{|c|c|c|c|c|c|}
\hline & $1479-80$ & $1485-6$ & $1486-7$ & $1492-3$ & $1504-5$ \\
\hline $\begin{array}{l}\text { Cloths of assize } \\
\text { by number }\end{array}$ & 528 & 389 & 395 & 399 & c. 400 \\
\hline Other goods by value & $£$ s.d. & $£$ s.d. & $£ \quad$ s.d. & $£$ s.d. & $£ \quad$ s.d. \\
\hline Foodstuffs & 410195 & 165190 & 22026 & $325 \quad 06$ & 359197 \\
\hline Cloth and clothing & 41144 & 13168 & 154140 & 199184 & 308175 \\
\hline Metals & 24100 & 600 & 1476 & 29126 & $53 \quad 44$ \\
\hline Miscellaneous goods & - & 166 & - & 1124 & 4309 \\
\hline Illegible goods & 134 & 0 & 11142 & 216 & - \\
\hline Total & 477171 & 186122 & 400192 & $559 \quad 52$ & $756 \quad 31$ \\
\hline
\end{tabular}

Sources: P.R.O., E 122/19/14, 20/5, 7, 9. For full details of goods other than cloth 1479-93 see W. R. Childs, 'Ireland's trade with England in the later middle ages' in Ir. Econ. \& Soc. Hist., ix (1982), Table 2 (pp 17-18). Figures for 1504-5 are based on Ada Longfield, Anglo-Irish trade in the sixteenth century (London, 1929), appendix, pp 216-18, 219.

Table 3: Imports to Bristol from Ireland by value

\begin{tabular}{|c|c|c|c|c|c|c|}
\hline & $1479-80$ & $1485-6$ & \multicolumn{2}{|c|}{$1486-7$} & $1492-3$ & $1504-5$ \\
\hline & $£$ s.d. & s. $d$. & $f$ & s.d. & $£ \quad s . d$. & s. d. \\
\hline Fish & 2,84349 & 1,411198 & 1,150 & 92 & 1,001410 & $2,464 \quad 8 \quad 8$ \\
\hline Skins & 13622 & $200 \quad 05$ & 1321 & 157 & 16553 & $446 \quad 710$ \\
\hline Cloth and clothing & 9989 & $\begin{array}{ll}159 & 02\end{array}$ & 110 & 26 & 265199 & 431131 \\
\hline $\begin{array}{l}\text { Miscellaneous goods } \\
\text { (including re-exports) }\end{array}$ & 1188 & 19116 & 20 & 26 & $\begin{array}{lll}28 & 3 & 8\end{array}$ & 146119 \\
\hline Illegible goods & - & - & 141 & 168 & - & - \\
\hline Total & 3,10044 & 1,790119 & 1,428 & 65 & 1,460136 & $3,49311 \quad 1$ \\
\hline
\end{tabular}

P.R.O., E 122/19/14, 20/5, 7,9. For full details of goods 1479-93 see Childs, 'Ireland's trade with England', Table 3 (pp 19-20). Figures for 1504-5 are based on Longfield, Anglo-Irish trade, appendix, pp 213-15, 219.

had its ups and downs, but it was longstanding and regular, and it is clear that Irish merchants and seamen were a vital part of it and much in evidence in some English ports.

It is impossible to quantify the importance of the English trade in Ireland's economy in the same way, because of the absence of detailed customs accounts for Irish ports, but England's proximity and range of available commodities suggest it would be a major market. The English trade was, moreover, welcome as an important earner of silver, since the balance of trade was always in Ireland's favour. This balance is clear at Bristol in 
both the fourteenth and fifteenth centuries, ${ }^{21}$ it remains even when the Irish trade at Bridgwater is taken into account, and was also true in Devon, as the inquiry of 1476 showed. Although some southern and western Irish ports may increasingly have exploited Iberian trade, merchants of the eastern Irish ports must still have found trade with England, with its high demand for fish, very attractive.

\section{II}

The numbers of Irish merchants engaged in the trade is harder to assess than the numbers of ships. This is because (as mentioned above) Irish merchants were of denizen status and paid the same duties as English merchants, and the customs collectors had no reason to identify them separately. In most cases we must judge nationality by name, which is always an inexact method. Many Anglo-Irish names were similar to English ones, and while the more distinctive names such as Casse, Lawless, Nangill and Roche almost certainly identify Irish merchants, and names such as White, Green, Blake and Walsh probably do, any single individual might be English. What is clear, however, is that most Irish merchants on the route bore Anglo-Irish names. Only occasionally is a Connel, Donnel, Donagghey or Flanagan to be found. ${ }^{22}$ This is not unexpected given the English government's restrictions on the interaction of Anglo-Irish and Gaelic Irish families and its limitations on the economic activity of the Gaelic Irish in English towns in Ireland.

In general terms, Irish ships probably carried the goods predominantly of Irish merchants, since there was always a tendency for merchants to use ships of their own locality. On this very rough basis, Irish merchants possibly made up a third to a half of those active on the route. At Bristol in 1485-6, for example, the Irish provided one-third of the shipping, which

${ }^{21}$ The following examples are taken from the few surviving poundage accounts for the late fourteenth century and the full-year accounts for the late fifteenth (P.R.O., E 122/16/4,21,17/10,18/13; for details see Tables 2 and 3). Cloths are valued at $£ 110 s$. each.

\begin{tabular}{llll}
\hline & \multicolumn{2}{c}{ Outward cargoes } & \multicolumn{2}{c}{ Inward cargoes } \\
\hline $1378-9$ (Nov.-May only) & $£ 163+661$ cloths & $=£ 1,154$ & $£ 695$ \\
$1391-2$ (Aug.-Dec. only) & $£ 540$ (including cloth) $=£ 540$ & $£ 1,075$ \\
$1403-4$ (Oct.-Mar. only) & $£ 146+742$ cloths & $=£ 1,239$ & $£ 2,091$ \\
$1479-80$ & $£ 478+528$ cloths & $=£ 1,271$ & $£ 3,100$ \\
$1485-6$ & $£ 187+389$ cloths & $=£ 771$ & $£ 1,791$ \\
$1486-7$ & $£ 401+395$ cloths & $=£ 993$ & $£ 1,428$ \\
$1492-3$ & $£ 559+399$ cloths & $=£ 1,157$ & $£ 1,461$ \\
$1504-5$ & $£ 756+400$ cloths & $=£ 1,356$ & $£ 3,494$ \\
\hline
\end{tabular}

${ }^{22}$ For example, Thomas Donachy, Cornelius Donell and Edward Kelly can be found in 1485-6 (P.R.O., E 122/20/5). 
carried about half of all Anglo-Irish trade that year, on behalf of 115 merchants, just over half of those engaged in the trade that year. ${ }^{23}$ Some of the merchants on the Irish ships were, of course, English, but similarly some of those on English ships were Irish. There is nothing unlikely in 100 or so Irish merchants and shipmasters visiting Bristol each year. Similar numbers probably frequented Chester, where a local customs account of 1404-5 identifies over 100 different merchants by their home town, and at least 75 were from Ireland. ${ }^{24}$ At least a few dozen Irish must also have visited the lesser ports of the south-west. Although estimates are inexact, the conclusion must be that a numerically strong group of Irish merchants was constantly coming to western England and probably handling a third to a half of Anglo-Irish trade.

The home towns of the Irish merchants were never specified in the English national customs, but evidence suggests that, not surprisingly, their origins could be broadly identified with the origins of the ships. In Chester in 1404-5, of the 75 identified by their home towns, 59 came from Dublin, Drogheda, Rush and Malahide, a further 15 from the smaller centres in the same region (Swords, Balrothery and Lusk, and Athboy in Meath), and one from Kinsale. This account does not give shipping details, but these origins reflect exactly the shipping recorded in later accounts. Similarly, there is little doubt that most Irish merchants at Bristol came from the areas round Wexford, Waterford and Cork. A lone local customs account for Bristol, for 1437 , records home towns for only 13 of the 100 masters and shippers on Irish ships, but goes a little way to confirm this. Eight came from Kilkenny, and one from nearby Callan; two came from further west (Galway and Kinsale), and two from further north (Rush and Drogheda). Some of the Kilkenny merchants, however, loaded goods not only on ships of Waterford (their nearest major port) but also on those of Kinsale, which makes clear, if we should have doubted it, that ship-owners sought goods where they could, and merchants used whatever shipping was available. Thus identifying the merchants through the shipping cannot be precise. Nonetheless, shipping probably reflects in a general way the home areas of the merchants, and we can be reasonably confident that Bristol's visitors came largely from the south and south-east, while Chester's came from the narrow area between Dublin and Drogheda.

Many of the shipmasters and merchants were regular visitors to England and built up longstanding connexions in port. Long-term activity is particularly easy to trace among the shipmasters. Robert Doude of Kinsale brought the St Mary Boat in and out of Bristol for twelve years between 1383 and 1396, and perhaps Richard Doude, who brought it in 1397, was his son. Peter Walsh started his visible career on the Katherine of Cork in 1390, and was master of the Trinity of Cork between 1394 and 1402. Thomas Steward brought the Trinity of Waterford in and out of Bristol, Bridgwater and

\footnotetext{
${ }^{23}$ Ibid.

${ }^{24}$ The account recorded home towns for 225 merchants, but many appear more than once, Wilson (ed.), Chester customs accounts, pp 103-16.
} 
Minehead for twelve years between 1475 and 1487. Thomas Yonge commanded various Cork ships in and out of Bristol over at least eleven years between 1475 and 1486 . Various members of the Roche family were masters and shippers for long periods: William commanded ships of Cork and Wexford between 1480 and 1486 at Bristol and Bridgwater; Edmund was master of Cork ships at Bristol and Bridgwater between 1480 and 1497; Philip was master of ships from Cork and Kinsale over twenty years. ${ }^{25}$ Possibly there were several with the same names, but there is nothing inherently unlikely in masters moving between towns. There is plenty of evidence of masters moving from ship to ship, and indeed Patrick Talant, an unemployed Irish shipmaster in Bordeaux in 1491, was hired by London merchants to bring the Spanish ship they had just bought there to England. ${ }^{26}$ Similar long-term activity is clear at Chester, where William Walsh was master of the Trinity of Howth between 1492 and 1497 and had possibly been so since $1479 .{ }^{27}$ Masters like these often brought their ships to England several times a year and were clearly professional masters commanding regular commercial vessels. We know far less about the ordinary crew members, but they probably came as regularly as the masters, and in some numbers. Many of the ships on the route were probably fairly small at thirty to sixty tons, but these might take crews of ten to twenty apiece. Irish seamen also crewed on Bristol ships. The large Trinity of Bristol, sailing for Andalusia and Oran in 1480, took on eight of her thirty-five crew when she called at Kinsale on the outward leg. The world of the seaman was particularly mobile, and international crews were as common in the middle ages as nowadays. The extent which this could reach is illustrated by the mutinous crew of the Mary of Kinsale, which comprised four Irishmen (one each from Wexford and Dublin, and two called Roche), ten men from Dartmouth, three Cornishmen, two Spaniards, two Welshmen, one certain and three possible Flemings (but Fleming was also an Irish surname), a Gascon, a Breton, and two men from ports on the Bristol Channel. ${ }^{28}$ But many of the boats shuttling back and forth between Bristol and Ireland probably had more homogeneous crews than that.

Irish merchants similarly traded for years in one place and must have built up strong business contacts. The repeated and regular appearances of men called White, Walshe, Roche, Nangill and Lawless suggest some strong family businesses, although relationships are impossible to discover and some of the names are common ones. Others are more distinctive in English records. Thomas Lynch and Patrick Galway were recorded several times in

${ }^{25}$ P.R.O., E 122, Bristol, passim.

${ }^{26}$ Ibid., E 159/268, Recorda, Michaelmas, m. 12v; the membrane number is misquoted in M. K. James, Studies in the medieval wine trade (Oxford, 1971), p. 172 n.1.

${ }^{27}$ C.R.O., Sheriff's Book 4, ff 14v, 16, 17v, 37, 58, 61, 63, 81, 82v (1492-7). Wilson identified part of Sheriff's Book 5, ff 52-6v, on which Walsh also appears as an account for 1479-80 (Wilson (ed.), Chester customs accounts, p. 150).

${ }^{28}$ T. F. Reddaway and A. A. Ruddock (eds), 'The accounts of John Balsall, purser of the Trinity of Bristol, 1480-1' in Camden Miscellany, xxiii (1969), pp 8, 15-19; Cal. misc. inq, vi, no. 220. 
the 1390 s. $^{29}$ Nicholas Mayo of Kinsale repeatedly traded in $1437 .{ }^{30}$ Others included Richard Casse, who traded for at least nine years between 1477 and 1486, and Dennis Bracy, active for over twenty years between 1465 and $1485 .{ }^{31}$ Although it is difficult to be sure whether some individuals were Irish or English, those with an almost exclusive interest in the Irish trade - men such as William Clifford, William Tirre, Matthew Frensch and William Lombarde, who were all busy for more than a decade - may be Irish. It was almost certainly from the ranks of these men with regular contacts that the mercantile immigrants came, whether it was through merchants finding it convenient to stay for ever-increasing periods, or installing factors for months or years at a time to run their business in Bristol. Both could also provide information at home about possible career opportunities for the Irish in Bristol or Chester.

\section{III}

As denizens, with a common language and cultural background, and with contacts already made in the commercial world, Anglo-Irish merchants would find little difficulty in settling in English towns, and for most of the time record-keepers had no need to identify them separately, thus hiding from us both their names and their numbers. However, denizen status was not quite the same as being fully English, and England's ambivalence to Irish immigrants is visible in several ways in the fifteenth century. In the first place, the central government made attempts to send Irishmen home in $1413,1417,1430,1431,1432$ and 1439 on the twin grounds of the defence of Ireland and the preservation of peace in England. These regulations should not have greatly affected the merchant community, because merchants of good repute and their apprentices were always exempt, but some merchants joined other Irishmen who preferred the security of personal licences of exemption from expulsion, perhaps to avoid any misunderstanding if the town government was ambivalent about Irish settlers. ${ }^{32}$ In the second place, although the tax in 1440 on alien settlers should not have affected the Irish, who were denizens, government instructions were not clear and the taxcollectors at first insisted that Irish settlers should pay. Thirdly, urban distrust of the Irish may be the reason why Irish immigrants seem rarely to have reached substantial urban office, but neither did many other new immigrants, and this is more likely to be die to the generally exclusive tendencies of town councils than to any particular hostility to Irishmen. ${ }^{33}$

Chester had a growing group of Irish freemen in the fifteenth century, and

${ }^{29}$ P.R.O., E $122 / 16 / 26,28,30,34$.

${ }^{30}$ Bush, Bristol town duties, pp 17-25.

${ }^{31}$ P.R.O., E $122 / 20 / 1,5,7$.

${ }^{32}$ Also exempt were bona fide graduates, lawyers, the religious and heirs to English lands: see Stat. of realm, ii, 173; Art Cosgrove, 'England and Ireland, 1399-1447' in New hist. Ire., ii, 530.

${ }^{33}$ Sometimes towns did prohibit Irishmen on town councils: see below, p. 37. 
seven of the sixteen new members of the Chester Guild Merchant in 1474-5 were already freemen of Dublin. ${ }^{34}$ This was part of a strong two-way movement between Chester and the Irish towns. For example, Christopher Hegley of Chester lived in Dublin with a Dublin wife; Richard Boys of Coventry came via Chester to Dublin, where he held a shop in 1471; William Waleys of Lancaster and Robert Langherst of Newcastle-upon-Tyne, both of whom described themselves as 'dwelling in Drogheda', probably arrived there through Chester; and the new guild in Dublin of 'English merchants trading to Ireland' was predominantly for men from Chester and the midlands. This may have been set up in competition to or as protection from the Dublin Guild Merchant and, if so, may indicate that Dublin merchants were becoming less welcoming to English merchants than before, but there is no evidence that Irish merchants felt a similar need for protection in Chester. ${ }^{35}$

London too had its Irish merchant immigrants, several of whom became closely involved in Iberian trade, along with Irish merchants from Bristol. Richard May, who operated his Portuguese trade through London, was the brother of Henry May, who migrated from Ireland to Bristol. ${ }^{36}$ Peter Alford, who regularly worked between Lisbon and London in the 1440s and 1450s, also had links with Henry May and may also have been Irish, perhaps a relative of Richard Alford of Dublin, who traded in Lisbon and had a tenyear safe-conduct from the king of Portugal in 1462.37

Bristol, like Chester, had a substantial number of Irish immigrants in its mercantile community. Bristol wills, although showing fewer Irish links than might be expected, ${ }^{38}$ nonetheless show some to have been strong. In 1382 John Bownes of Bristol bequeathed lands, tenements and rents in Drogheda to his wife and made bequests to St Peter's and to the friars of Drogheda; and in 1396 John Tostrong bequeathed all his lands and rents in Waterford to Alice Werminstre. The most interesting case is that of John Bannebury of Bristol. In 1404 he left two water mills, tenements and rents in Limerick to his wife and bequests to the Friars Minor and the parish church in Limerick. His name sounds authentically English, but Bannebury first came to Bristol as John Toky of Limerick. As John Toky he was already a substantial merchant. He exported seventy cloths in 1378-9, shipped sixty-five lasts of hides (13,000 hides) from Limerick to Flanders in $1381,{ }^{39}$ and shipped thirty cloths to Ireland in 1382. Thereafter he took the name Bannebury and appears reg-

${ }^{34} \mathrm{~K}$. P. Wilson, 'The port of Chester in the later middle ages' (unpublished Ph.D. thesis, University of Liverpool, 1965), p. 94.

${ }^{35}$ Ibid., pp 91-4; P.R.O., C 1/43/33, 44/278. The absence of Bristol merchants in the Dublin guild is not surprising, given their relative lack of interest in Dublin trade, as recorded in the customs accounts.

${ }^{36}$ For Richard May's career see below, pp 37-8.

${ }^{37}$ P.R.O., PRO 31/8/153, ff 648-51.

${ }^{38}$ Wadley, Notes \& abstracts of wills reproduces 289 of those wills recorded municipally before 1530 ; of these, only three have reference to Ireland. G. H. Nicolson, 'The medieval wills of Bristol, with special reference to those of merchants' (unpublished M.A. thesis, University of Birmingham, 1970), app. 3, calendars those recorded centrally, and similarly few have reference to Ireland.

${ }^{39}$ Cal. close rolls, $1381-5$, p. 47. 
ularly as such in customs accounts between 1383 and 1402, during which period he shipped much cloth to Spain, Portugal, Gascony, the Bay of Bourgneuf and Ireland. In 1390 he served as bailiff, in 1391 as sheriff, and in 1398 as mayor. It is not clear why he changed his name, as he clearly did not intend to deny his Irish origins: he kept his Limerick property and still traded with Ireland. How many more seemingly English names hide recent immigrants is impossible to say. Not all known Irish immigrants left Irish bequests. The indisputably Irish Henry May gave no evidence whatsoever of his Irish origins in his will in 1466.

Bannebury presumably met little hostility and reached the mayoral office, but other Irish immigrants seemed more suspicious about Bristol's attitude to them. Seven went to the expense of buying individual exemptions after the expulsion order of 1413. These were Nicholas Devenysh, Philip Faunt, John Stone, John Aylward, Thomas Cogan, Roger Lybbe and Roger Baatte (who was already a burgess of Bristol). Some of the seven were perhaps artisans, and therefore needed protection, but John Aylward and Nicholas Devenysh were certainly merchants of some substance. John Aylward can be traced from 1395 exporting cloth in amounts ranging from 11 to $42 \frac{1}{2}$ cloths to Ireland and Bayonne; and Nicholas Devenysh can be found from 1399, when he exported ten cloths to Ireland. There seems no reason for these two to buy licences, unless they feared Bristol might deny them status as merchants 'of good repute'. Yet Devenysh's family continued to trade through Bristol and clearly integrated perfectly well. They provided some of the few Irishmen to reach office in the fifteenth century. Devenysh himself served as bailiff in 1417; his son Thomas (who died in 1426 and was probably born in England) served as bailiff of the Tolsey court; his grandson Nicholas (almost certainly born in England) was still living in Bristol at his death in 1459, when he left another Thomas as son and heir. ${ }^{40}$ By 1440 this family was clearly no longer considered 'alien', and the second Nicholas did not appear on the alien subsidy rolls. However, another Devenysh named John - possibly a relative and certainly a more recent immigrant, was charged the alien subsidy that year.

Some Irish shipmasters also settled and based their careers in Bristol. Skilled Irish masters were employed by Bristol owners on an ad hoc basis from time to time, but others regularly commanded Bristol ships in nonIrish contexts and should probably be counted as immigrants rather than transients. Germanus Lynch worked several routes out of Bristol in the 1470 s, taking the Mary of Bristol to either Bordeaux or northern Spain in 1473, the John Evangelist to Iceland 1478, and the Michael of Bristol to Ireland in 1479-80.4! Dennis Galway was another who made a career in Bristol, working exclusively on the Iberian run for ten years. His decision to move to England to concentrate on continental sailings is interesting, given the belief that western Ireland's direct links with Iberia were increasing at this time. Either these were still limited, or Bristol owners were employing a man they knew to be already experienced on the route. He took the

\footnotetext{
${ }^{40}$ Nicolson, 'Medieval wills of Bristol', app. 3 .

${ }^{4 !}$ P.R.O., E 122/19/10, 13, 14, 161/31.
} 
Michael of Bristol to Huelva about 1478 and to Seville in the winter of 1479-80. In 1485-6 he was continuously employed, sometimes with little time ashore between voyages, taking the Nicholas of Bristol to Lisbon (23 October 1485 - 24 January 1486), the Michael to Huelva (26 February 22 May 1486), and the Mary Fonsse to the Algarve (22 August 1486). ${ }^{42}$ Commanding large ships on long-distance routes certainly paid masters better in terms of wages and trading opportunities, and ambitious and adventurous navigators probably found better and more regular jobs in Bristol.

The alien subsidy rolls of 1440 and 1441 record Irish settlers despite their denizen status, and are very useful to us, although the collection of the tax was undoubtedly intensely irritating to the Irish who were called on to pay it. ${ }^{43}$ The first roll shows that probably at least one-quarter of the aliens resident in Bristol were Irish. Total numbers are difficult to assess, since nationalities are not always recorded, but 'aliens' with surnames of White and Walsh were no doubt Irish, as were Geoffrey Sligo, Dennis Kinsale, Walter Waterford, and a string of servants, such as German Irish, Elena Irish and Anastasia Irish. A few others are identifiable as Irish from other contexts, such as Thomas Walshe, tailor, Thomas Fraunces, weaver, and Nicholas Hoker, fishmonger, who were three of Henry May's Irish supporters in his lawsuit in 1456 (see below). How many of the taxpayers were merchants and seamen is difficult to assess, since occupations were not consistently recorded. A few were described as shipmen or mariners, and a few may have been merchants, although these were supposed to be exempt. Henry May's name certainly appears, and Nicholas Todde, William Tirre and William Warde may be the traders to Ireland of the same names. On the other hand, there is no reference to George Roche, also a substantial merchant and another of May's supporters in 1456. Roche's Irish servants were listed in at least two parishes, which suggests two separate establishments, possibly shops, but he himself was not on the list. He was certainly Irish-born, since he was so described in 1456 when he supported Henry May, but he may already have been a merchant of sufficient substance to be exempt without question, while the others were at earlier stages of their careers. Like a number of other immigrants, Roche seems to have turned his back on Irish trade and directed all his energies towards trade in Iceland, Iberia and Bordeaux, and by 1440 he was working with major figures such as Canyngs, Spring and Alberton for licences to trade in Iceland.

Bristol's attitude to the Irish seems more ambivalent than that of London and Chester, perhaps because numbers were larger than in London, and Bristol did not feel so dependent on Irish trade as did Chester. We find

${ }^{42}$ Ibid., E 122/19/13, 14, 20/5, 7.

${ }^{43}$ Ibid., E 179/113/103, 104. See Bolton, 'Irish migration to England', Table 1 (above, pp 5-7). The roll for 1440 is badly worn and incomplete. On the roll as it survives now about 218 names are legible. I have been more positive than Dr Bolton in my identification of Irish immigrants to Bristol: 22 were certainly Irish and a further 28 almost certainly so (i.e. a total of 23 per cent); at least a further 11 were possibly Irish. The roll for 1441 is well preserved but contains only 381 names; on this some 24 are reasonably identifiable as Irish ( 6 per cent). 
specific complaints by Bristol men that local weavers were taking Irish apprentices who failed to stay the full seven years, and in Bristol in 1439 (one of the years when the government tried to force Irish immigrants back to Ireland) it was declared that the mayor should be liable to a $£ 20$ penalty if he accepted anyone onto the town council both of whose parents were Irish and who had been born in Ireland. In the same year the ordinances of the hoopers' guild forbade Irish apprentices. ${ }^{44}$

Bristol also provides us with the best documentation of harassment of Irish merchant settlers in the case concerning Henry May in 1454-5. This was most unusual in its intensity, and it may also have been unusual in its occurrence, since other evidence of Irish masters and merchants from a variety of sources shows them fitting in perfectly well in Bristol. The case is, however, worth examining in some detail to illustrate both the success and the problems which immigrants might experience in Bristol. Henry May was one of the most colourful additions to Bristol's citizens and another of those who turned their backs on Irish trade in favour of wider opportunities. His business stretched from Portugal to Iceland, but he maintained contact with other Irishmen in Bristol and, like Roche, continued to take Irish servants and apprentices. His clash with the Bristol authorities was spectacular, perhaps as much because May was forceful and litigious as because he was Irish. Quite apart from his legal battles with two Bristol mayors, he sued in the chancery court on at least two other occasions; he sued other merchants in staple courts; and he was himself subsequently sued in chancery. Although he clashed with the town council in the most public way possible, he continued to run a profitable business in Bristol until his death in 1466.

May's family connexions with Bristol were probably well established before he settled. The relationship of the several merchants named May is not clear, but it is likely that some were of the same family. Both a Richard and a Thomas May traded into Bristol on Irish ships in the late fourteenth and early fifteenth centuries, but their connexion with the Mays who appeared in the $1430 \mathrm{~s}$ is unclear. The simultaneous appearance of Henry and Richard May as cloth exporters to Iberia in 1432 and their subsequent connexions with each other suggest that they may have been brothers. Possibly they were sons of parents who emigrated to Bristol, but Henry at least had been born in Ireland. He settled permanently in Bristol, but Richard moved to London, where in March 1443 he can be traced importing oil and wine from Lisbon. His continued association and possible kinship with Henry is visible in the early summer of that same year, when he was swept up into the conflict between Henry and João Veilho of Portugal. When Veilho's supporters in Lisbon were looking for ways to put pressure on Henry, they had Richard arrested, presumably because of his known relationship with Henry, although he was then working for London merchants and arranging a cargo for the George Heron of London. His association with Henry may be further confirmed when the London owners of the George tried to squeeze compensation from Henry for their ship's delay in 
Lisbon. Despite his spell in a Lisbon prison, Richard maintained his interest there: in 1452 he received a safe-conduct from the king of Portugal to send his ship Salvador to Lisbon, and in 1457 he imported Iberian goods into London on a ship commanded by Nicholas Irissh. ${ }^{45}$ This was an interesting enterprise because the English shippers on that vessel included the Bristol merchants John Jay and William Wodehouse and the London merchants Stephen Stechmersh, Bartholomew James and Peter Alford, ${ }^{46}$ all regular Lisbon traders, to whom Henry May had initially sent João Veilho for help. Altogether the ship is a microcosm of the links between London and Bristol, Lisbon and Ireland.

Two other Mays worked in Bristol alongside Henry. Richard, who was working through Bristol in 1461, 1465 and 1469, was almost certainly Henry's apprentice over whom conflict broke out in 1456, rather than his brother. ${ }^{47}$ John was possibly another kinsman, much involved in the wine trade and shipping. A John May loaded wine aboard the Trinity (which was probably Henry's ship) at Bordeaux in 1443, and ten years later a John May had goods on the Julian of Bristol on its complex voyage between Portugal, western Ireland, Plymouth, and the Low Countries, on which a Nicholas Mody was purser. In 1454 Henry and John jointly bought a trading licence, and in 1455 John bought licences for the Mary and the Christopher of Bristol to trade; probably all these licences were for the Bordeaux trade in the aftermath of England's loss of Gascony. Connexion with Henry is clear again when, sometime before 1457 , Henry was John's pledge in a suit of debt against Nicholas Morthy of Youghal (Nicholas Mody, the purser of the Julian?). Like Henry, John was a ship-owner, and built the carvel Raphael for 800 marks ( $£ 5336 s .8 d$.), an investment so high that he needed immediately to sell one-quarter to John Gregory, but he kept his interest in the Raphael, which he sent to the Baltic in $1468 .^{48}$

Of all the Mays, Henry made most impact in Bristol. He became a freeman of Bristol about 1434, soon after he is first recorded trading to Spain in 1432. Although he must already have been a substantial merchant in the early $1440 \mathrm{~s}$, he was one of the few merchants to appear in the alien subsidy rolls. These show that in 1440 he lived in St John's parish and employed three Irish servants - William May, William Cradock and Elena Irisshe - of whom Cradock was still with him in $1441 .^{49}$ By the time of his death in 1466 he had moved to the parish of St Stephen. His trade concentrated on

${ }^{45}$ P.R.O., E 159/210, Recorda, Michaelmas, m. 34; ibid., E 122/77/4, 203/4; ibid., C 1/9/488-91 (printed in E. M. Carus-Wilson, The overseas trade of Bristol in the later middle ages (Bristol, 1937), no. 87); P.R.O., PRO 31/8/153, f. 642.

${ }^{46}$ Alford was possibly also an Irish immigrant and associated with Richard Alford: see above, p. 34. James was born in Lisbon of an English father (Cal. pat. rolls, 1441-6, p. 435).

${ }^{47}$ PR.O., E 122/19/1,3, 4, 6.

${ }^{48}$ Ibid., E 101/194/3; ibid., C 1/17/30,24/211-17 (printed in Carus-Wilson, Overseas trade of Bristol, no. 120), 32/289, 44/151; Cal. pat. rolls, 1467-77, p.168; Carus-Wilson, op. cit., nos $113,118$.

${ }^{49}$ P.R.O., E 179/113/103, 104 
Spain, Bordeaux and Iceland, not Ireland. By 1443 he was the owner of a ship, the Trinity, which rescued a Portuguese carvel from pirates. Lawsuits following the rescue revealed not only that Richard May was trading between London and Lisbon as mentioned above, but also that Henry was well acquainted with the established London merchants who traded in Lisbon. In 1443 the Trinity was used in the Bordeaux wine trade, with John May as one of the shippers, and in the same year Henry also bought a sixyear licence to use it in trade with Iceland. With Patrick Davy of Bristol and David Selly of Westminster he also bought a licence to victual Bordeaux and expected to use an arrested Spanish ship for this. In 1454, in association with John May, and in 1459 alone he bought further licences to trade (probably also in Bordeaux), and in 1460 was trading to Bordeaux in the Julian of Fowey, when it was seized by the earl of Warwick. His litigiousness, perhaps exacerbated by political anger, is apparent in his suit against the owners of the Julian for the loss of the voyage, although it was hardly their fault. He twice lost his case, but started a third suit against them in the staple court, from which they petitioned to have the case removed again to chancery. ${ }^{50}$

His career displays evidence of minor involvement in politics. He was known locally as a Lancastrian sympathiser, a link which may have been formed through residual Irish connexions, especially with James Butler, earl of Ormond, later earl of Wiltshire, and one of Henry VI's commanders. May bought wheat for Wiltshire, which was later seized for the earl of Warwick, and May showed his usual litigiousness by suing Warwick's servant for the seizure. Henry VI's ordnance master also used May, sending gunpowder into his safe-keeping at Bristol, but William Canyngs, the mayor, 'knowing the said Henry May to be of like disposition and assistant to James earl of Wiltshire', arrested it and put it to various Yorkist uses. ${ }^{51}$ If May had sympathy in the Lancastrian direction, this can only have been intensified by his loss of profits in 1460 when the Julian was commandeered at sea by the earl of Warwick to accompany the duke of York to Ireland.

Henry May's final will was drawn up and proved in October $1466 .{ }^{52} \mathrm{His}$ burial place was to be St Stephen's church. Small bequests were made to its rector and to the orders of friars in Bristol, to his two executors (John and William Coston) and to the three supervisors of his will (John Shipward senior, Richard May, probably his apprentice, here simply called merchant, and John Young, merchant). Bequests suggest a man who enjoyed his wealth and fine clothing. This included his best blue robe trimmed with marten fur, a robe of scarlet trimmed with fur, a green girdle embroidered with silver, and a purse of gold cloth. The residue of his wealth went to his wife, Joan, but there is no mention in the will of children or any other relatives. There

\footnotetext{
${ }^{50}$ Ibid., E 159/210, Recorda, Michaelmas, m. 34; ibid., E 101/194/3; ibid., C 1/9/488-491 (Veilho case; printed in Carus-Wilson, Overseas trade of Bristol, no. 120), 19/409 (Motrico ships), 27/383, 471 (loss of voyage to Bordeaux; printed in Carus-Wilson, op. cit., nos 142, 143); Carus-Wilson, op. cit., nos 87, 90, 113, 138.

${ }^{51}$ P.R.O., C 1/29/542; E. W. W. Veale (ed.), The Great Red Book of Bristol (Bristol Record Society, IV, Bristol, 1933), pp 136-8.

${ }^{52}$ Nicolson, 'Medieval wills of Bristol', app. 3.
} 
is also no indication whatever of any ties with Ireland, except through the use as supervisors of Richard May, who was certainly Irish, and John Young, who may have been. In the light of the acrimony over Henry's loss of the town freedom under John Shipward's mayoralty, the use of Shipward as a supervisor and a bequest to him seems unusual, but perhaps genuine reconciliation had taken place, especially as both were known Lancastrian sympathisers. ${ }^{53}$

Henry May's noisiest impact on Bristol was clearly made when he clashed with the town council in 1454-5. The impact was long-lasting, and when Ricart was asked in 1479 to write a history of Bristol's great events, this twenty-year-old case made up one of his longest entries. The case is interesting because May's Irishness is part of the issue and because it shows a network of Irish support working within Bristol. The problem first arose, without any initial racial overtones, under Mayor Richard Hatter (September 1454-5), whom Henry sued in chancery over the council's failure to admit his apprentice Richard May to the freedom of the town. ${ }^{54}$ Hatter claimed that admission to freedom was at the discretion of the mayor, sheriffs, chamberlains and common council and had been so since Bristol became a shire in 1373 . He also claimed that to be a burgess, a man must have been apprenticed to a burgess; must show indentures properly sealed to prove that seven years had been served; must show that he had not bought and sold on his own behalf up to then; must bring a burgess to witness all the above and that the applicant was of good character; and then must pay the sum due, which was at the discretion of the mayor. Hatter claimed that Richard May had not come personally to prove his case, nor presented his indentures, nor paid the fee; therefore he had not been admitted.

Henry May rejected this. He claimed that applicants did not have to produce the indentures, since if they had been lost, a testimony by the master was enough; that it was customary for apprentices to trade on their own account with non-burgesses, provided they had the permission of their master; that the entrance fee was not at discretion but fixed at $2 s$., unless more was due for 'the necessity of the town', and in that case it must be agreed in a full meeting and all burgesses must pay. He agreed that Richard had not offered any money, but argued that he did not have to do so until he was admitted, which he had not been. Henry declared that he himself, on his own testimony, had presented Richard as a seven-year apprentice who was eligible to enter at $2 s$., but the chamberlains and mayor had declared the fee would be $104 \mathrm{~s}$. because Richard was Irish-born. This was in accordance with a recent town ordinance made by the mayor and council, which Henry considered unreasonable. He would therefore neither pay nor let Richard pay. Hatter's legal rejoinder claimed that Henry was now departing from his original case. He denied that Henry had presented Richard; reasserted that Richard could not be admitted without the indentures; and denied that the

\footnotetext{
${ }^{53}$ For Shipward's political leanings see Bickley (ed.), Little Red Book, pp 130-31.

${ }^{54} \mathrm{No}$ original petition survives, but Hatter's reply, May's replication and Hatter's rejoinder make the problem quite clear (P.R.O., C 1/17/213).
} 
council had said anything about any ordinance, which in any case was never made. ${ }^{55}$ There was no judgement recorded in the surviving documents of the case, possibly because the case was already fast escalating into a first-class local row.

The next step in the affair seems to have been an ordinance promulgated under the next mayor, John Shipward (September 1455-6). This was said to be necessary because of the untruths, deceits, conventicles, assemblies, taxcollecting (perhaps for legal costs) and other misgovernance of Irishmen born in Ireland against the goodwill and prosperity of Bristol. Those held to be especially responsible were Harry May, George Roche, Thomas Walsh, tailor, Thomas Fraunces, weaver, and Nicholas Hoker, fishmonger. Because of their 'slanders and untrue language published and pronounced' against the mayor, sheriff, common council and other town notables, the council decreed that they should no longer be accepted as burgesses, nor be allowed to trade as burgesses, and therefore were to be 'discommoned' of all liberties and franchises until each one 'sufficiently declared and excused themselves' before the mayor and council. ${ }^{56}$ May's response to this was further litigation. Declaring that he had been twenty-two years a commoner and freeman of Bristol, and that Shipward, at the instigation of Hatter, had disenfranchised him and the other four 'well disposed to him', he requested a remedy through the court of chancery. ${ }^{57}$ Shipward's reply stands on the authority of mayor, sheriff and common council to admit, and therefore also to 'discommon', anyone they chose; and he declared that he could not in any case reinstate May on mayoral authority alone. Judgement was given in May's favour, and Shipward was ordered to restore them all on pain of 500 marks.

May's victory did not last long. His next petition to chancery complained that Shipward had duly restored them all to the freedom of the town on Monday, but by four o'clock the following Friday afternoon had put them all out again, and sent men to board up their shop windows to stop them trading on pain of 1,000 marks. It may be this action which drove May and three of his supporters (i.e. all except Roche) to enter yet more petitions in chancery, alleging unfair exactions of obligations for $£ 20$ from May, and for $£ 10, £ 5$, and $£ 36 s .8$ d. from the other three, in contradiction to the chancellor's judgement that they should be readmitted to the freedom without loss of goods. This case was called to chancery in March 1458, but May's three supporters withdrew their petition, perhaps under pressure from the mayor, now William Coder. May possibly did likewise, as no further result is recorded in chancery. Ricart recorded that May and the others had to repurchase their freedom 'with the blodde of theyre purses, and with weping

\footnotetext{
${ }^{55}$ It appears that there had been a change of policy sometime before 1445 , by which time the charge for foreign apprentices, including the Welsh, was $£ 5$ unless they had completed a full seven-year apprenticeship (Nicolson, 'Medieval wills of Bristol', p. 32).

${ }^{56}$ Veale (ed.), Great Red Book (Bristol Record Society, VIII, Bristol, 1938) p. 54.

${ }^{57}$ P.R.O., C 1/17/213a; ibid., C $1 / 17 / 214$ is similar, but omits Roche and adds occupations for others.
} 
ien, knelyng on their knees, ${ }^{58}$ perhaps a reference to the exactions listed above.

The whole case is interesting for its manifestation of the continued distinction made by urban government institutions of 'Irish-born' even though the Anglo-Irish were legally denizens and even when individuals such as May were successful merchants and ship-owners who had long been freemen. It is also interesting for its illustration of the way in which a merchant such as May might make his living trading with continental Europe without displaying any trace of his Irish origin in his overseas trading career, yet continue to draw his servants, apprentices and associates from Ireland. Whether his supporters were essentially his normal social circle of 'Irishborn' friends, or whether they came together at this time specifically over the issue of 'Irishness', is unfortunately impossible to say.

\section{IV}

To conclude a study of Irish merchants in England on a hostile note would be wrong. May's career as a whole shows successful integration into Bristol life, and by 1466 he had clearly made his peace with Shipward. Easy relationships, such as those of Bannebury and Devenysh and of the shipmasters Lynch and Galway, were more typical. Trading relationships were generally good, and Irish trade was locally important to the ports in the west of England. Nonetheless, government ambivalence to Irish immigration and its original inclusion of Irish immigrants in the alien groups to be taxed in 1440 kept the issue of 'Irishness' alive. Merchants of good repute were generally exempt from such regulations, but if economic times became difficult, anyone perceived as 'foreign' might find themselves harassed. England's economic climate was not as difficult as that elsewhere in Europe in the early to mid-fifteenth century, but it was not easy and aliens were blamed. In 1430 credit was forbidden to alien merchants; in 1436 The libelle of Englyshe polycye advocated plans to limit the foreign role in English trade and was especially critical of Venetian monetary practices; in 1440 regulations to ensure that foreign merchants stayed with English hosts were to be enforced, and the alien subsidy was introduced. The general European bullion shortage and trade recession was later exacerbated in Bristol by the loss of the large Gascon market in 1453. Bristol merchants and the town council might well be feeling short of money, edgy and protectionist in the 1440s and 1450 s, and Irish activity on Bristol's quays was highly visible. On the other hand, Ireland was one of Bristol's major markets, especially useful for fish supplies, and on the whole at Bristol, like Chester, Irishmen were simply accepted as a natural and regular part of the trade. As denizens, they needed no special privileges, but were free to come and go, to stay as long as they wanted, and to deal with whom they pleased, always provided they abided

${ }^{58}$ Ibid., C 1/17/215, 26/102-5; Robert Ricart, The maire of Bristowe is kalendar, ed. Lucy Toulmin Smith (Camden Society, new ser., vol. 5, London, 1872), p. 41. 
by the municipal regulations about non-burgess trading. These restrictions were no worse for them than for incomers from English areas. Most visiting Irish merchants functioned without trouble, and most of the Irish who chose to settle were probably absorbed without too much difficulty.

Just how many settled permanently is difficult to assess. The English government in the early fifteenth century clearly thought that the level was too large and attempted repatriation in the interests of defending Ireland; but the alien subsidy records show that, despite government attempts at repatriation, the number of Irish immigrants was still high in the 1440s. In Bristol the Irish made up at least 23 per cent of alien immigrants and probably more. Neither these records nor exemptions from expulsion, however, are ideal for an investigation of Irish merchants. Bona fide merchants should not have been included in the expulsion orders, nor, it seems, were they always charged the alien subsidy. The sheer difficulty of identifying the Irish clearly in many records indicates how easily most could integrate. The situation was probably much as it is now. Legally the Anglo-Irish had no restrictions on their movements, and socially there was little problem. The language and culture of the merchant communities were very similar, and there was no Irish ghetto: at Bristol the Irish settled in all parishes, although the identifiable merchants and seamen seem to have been concentrated in the parishes of St Michael and St Stephen, and one area was known as the 'Irish Mead'. The lack of Irish immigrants in urban office is not surprising and should not be taken as a sign of anti-Irish prejudice. Given the wealth of some of those in the town hierarchy and the general exclusiveness of town councils, it could easily take a couple of generations or more for immigrants to work their way up the social and political ladders to join the ruling classes. By that time they had intermarried and reintegrated (for, after all, most were descendants of emigrants from England), and their own descendants would no longer be properly seen as the Irish in England, but as English-born.

WENDY R. CHILDS School of History, University of Leeds 